Sills, S. and Chowthi, N. 2008. "Becoming an OFW: renegotiations in self-concept among Filipina factory workers in Taiwan" Asian and Pacific Migration Journal. 17 (2).

Made available courtesy of Scalabrini Migration Center: http://www.smc.org.ph/

\title{
Becoming an OFW: Renegotiations in Self-Concept Among Filipino Factory Workers in Taiwan
}

\author{
Stephen J. Sills and Natassaja Chowthi \\ University of North Carolina, Greensboro
}

\begin{abstract}
This study focuses on overseas Filipino workers (OFWs) in Taiwan and probes into how their migration experiences shape self construction. Data for the study came from surveys, key informant interviews, Twenty Statement Tests (TST), and observations in field studies conducted in Taiwan in 2003 and 2007. Analysis of self-concept statements on the TST showed that among women OFWs the self became more individualized and less embedded in the social roles in Taiwan than when they were in the Philippines. In contrast, the few male workers in the study registered a slight increase in their social roles. In general, OFWs found little opportunity to become integrated into Taiwanese society. In the face of exclusion in the host society, we argue that OFWs exercised social creativity, reinforcing their national identity as Filipinos and embracing the role as "modern-day heroes" of the Philippines.
\end{abstract}

\section{Introduction}

The perspectives on international labor migration have significantly expanded to consider the multi-level and multi-dimensional features of the phenomenon. Amidst the various stakeholders operating at various levels, the internal transformations experienced by workers on the move also merits scrutiny. As migrant workers move from one milieu to another, they enter a new social space which may require renegotiations in group membership. Within the context of new cultural norms and values, the self 
experiences a shift in role expectations and statuses, particularly in being defined as aliens, foreigners, or the "other."

The development of the individual self as it relates to the social structure is a central concept in social psychology. In Mind, Self and Society (1962), Mead explains, "The self, as that which can be an object to itself, is essentially a social structure, and it arises in social experience. After a self has arisen, it in a certain sense provides for itself its social experiences, and so we can conceive of an absolutely solitary self" (p. 140). Accordingly, while there cannot be a 'self' without social interaction, the self, once formed, in Mead's model, exists independently of the structure. While this conception provides for a great deal of humans agency at the individual level, it tends to neglect the continuing role of the social group and its influence on selfidentity especially in non-Western contexts (Smith and Bond, 1998). The notion of the self as reflexive and involved in the process of self-construction is important in the present study. This meta-theoretical assumption was central to the methodology employed in this project, as much of the data were derived from reflective and introspective interviews and the Twenty Statements Test (TST).

De Korne, Byram, and Fleming (2007) noted in their study of long-term immigrants (i.e., those living in the destination country for more than 20 years) that over time, many of the participants, even those who originally preferred the host culture, realized how deeply their home culture was a part of their identity. Many eventually developed a flexible, hybridized identity. Even though some participants ultimately preferred one culture over the other, they all felt a sense of belonging in both places, and reported feeling like a "global citizen" (p. 292).

There is some evidence in the literature suggesting that changes to the self may be transitory. Bagnoli (2007) conducted a small longitudinal study of young European migrants (10 English migrants in Italy, and 10 Italian migrants in England) to observe shifts in identities resulting from their migration experience. For some, the experience was a "vacation" from their permanent identity, while many others attempted to hybridize the two cultures, forming a new identity. Those who viewed the experience as an identity vacation tested new identities while abroad, but ultimately returned to their former identity upon their return home. Those who attempted to mesh the two cultures into a new identity experienced difficulties and ultimately only a few succeeded in obtaining a hybridized identity.

\section{Focus of the Study}

The experience of overseas Filipino workers (OFWs) in the export processing zones working on short-term visas poses questions about self construction. In such a setting, groups are constantly reformulated based on mass 
hirings and layoffs. Individual migrants all eventually return home, possibly to reassume identities left behind or to become "hybridized" in some way resulting from their experiences during their time abroad.

As "foreigners," "outsiders" or the "other" in Taiwan, OFWs must reconsider their reference groups. For the most part, the review and reassessment of self is an internal process and occurs at the individual or micro-level. Migrants may experience an initial loss of self-esteem (as the minority out-group), which will require a process of re-building a sense of worth by strengthening their group identity. The nature of reception offered by the destination country is crucial in migrants' self-concept. Exclusion and rejection by the host society may result in return migration, onward migration, or the formation of an ethnic enclave. It may result in migrants developing a negative self-concept or an eventual rejection of the homeland culture an attempt in favor of assimilation.

This article focuses on the experiences of overseas Filipino workers (OFWs) working in and around an export processing zone in the south of Taiwan. Based on field work conducted in 2003 and 2007, the article presents findings of an inquiry into how the experience of being a migrant worker bears on the self-concept of OFWs working in the manufacturing sector. The study attempted to probe into indicators of self-concept before coming to Taiwan and while working in Taiwan and the renegotiations in OFWs' self-concept as they move across geographical, economic, social and cultural borders. Following the argument of Tajfel (as cited in Smith and Bond, 1998), we hypothesized that since OFWs may be unable to join other minority groups and have no access to social opportunities in Taiwan, the prospects for social mobility are rather nil. Also, they cannot seek outright social change in view of the risks of deportation. One possibility that is open for them is to exercise what Tajfel referred to as social creativity, that is, reinforcing the cultural heritage of their homeland.

The rest of the article is organized into five parts. Part 1 discusses the Philippines-Taiwan migration system. Part 2 outlines the methodological approach of the study. Part 3 describes the research site and the characteristics of OFWs. Part 4 presents the major findings. The conclusion in Part 5 summarizes the main findings and highlights insights from the present study.

\section{The Philippines-Taiwan Migration System}

\section{Labor Migration from the Philippines to Taiwan}

By the 1990s, when Taiwan formally launched a system for bringing in foreign workers, the Philippines was entering its third decade of labor migration. The 1990s also coincided with increasing levels of female migra- 
tion from the Philippines. By the mid-1990s, women outnumbered men among the new hires and land-based workers (Asis, 2003). A history of emigration, coupled with governmental promotion of overseas work, a legalized system of foreign recruitment and placement, and continued reliance on the economic support provided from remittances of OFWs have created a culture of labor migration in the Philippines (Abella, 1993; Martin, 1993; Tan, 2001; Sills, 2007). Migration, thus, has become a way of life for Filipinos. The impact of migration on gender relations, child rearing, the extended family, marriage, and other social structures has been widely discussed (Asis, Huang and Yeoh, 2004; Parre as, 2005; Semyonov and Gorodzeisky, 2004; Yeoh, 2006; Parre as, 2005; Devraj, 2001). Despite concerns over the social costs of migration, the government of the Philippines continues to promote the exportation of labor as a means of reducing internal pressure and providing a source of funds produced by remittances to sustain the country. With the expectation that at some point one will go abroad to gain work experience, and economic capital to relieve the financial burden of families, the choice for potential migrants becomes not whether one will migrate, but where one will go. The geographic proximity of the Philippines to Taiwan means low travel cost between the countries, making it an easy choice for a first foray into international labor.

On the other end of the migration system, Taiwan was transformed into a country of immigration in the 1990s. With its robust economy and full employment, Taiwanese employers turned to foreign labor to counter the high cost of labor in Taiwan (Skeldon, 1992; Martin, 1993; Chan, 1999). Simultaneously, Taiwanese women entered paid employment, leaving vacancies in household or domestic work, which was traditionally assigned to women (Lan, 2006). Inter-governmental negotiations led to formal ties between placement agencies in the Philippines and labor brokers in Taiwan, supplying a growing number of export processing zones (EPZs) and private homes with young, educated, skilled, yet low-cost workers from the Philippines. Initially, OFWs in Taiwan were predominantly male, but female migrant workers quickly outnumbered male workers (Figure 1). Women were considered best for the "delicate work" of electronics manufacturing as well as the feminine labor of the household. Presently, women migrant workers account for as much as a quarter of the foreign workforce in Taiwan (Council of Labor Affairs, 2008).

Taiwan presents a difficult receiving context where work conditions are harsh and opportunity for social integration is almost nonexistent (Sills, 2007). The conditions under which Filipinas migrate have been described as dehumanizing and marginal (Lan, 2003; Loveband, 2004). Loveband (2004) discussed the commodification of the workers, while Lan (2003) highlighted the subordinate status of domestic workers in Taiwanese homes. 
FIGURE 1

FILIPINO WORKERS IN TAIWAN

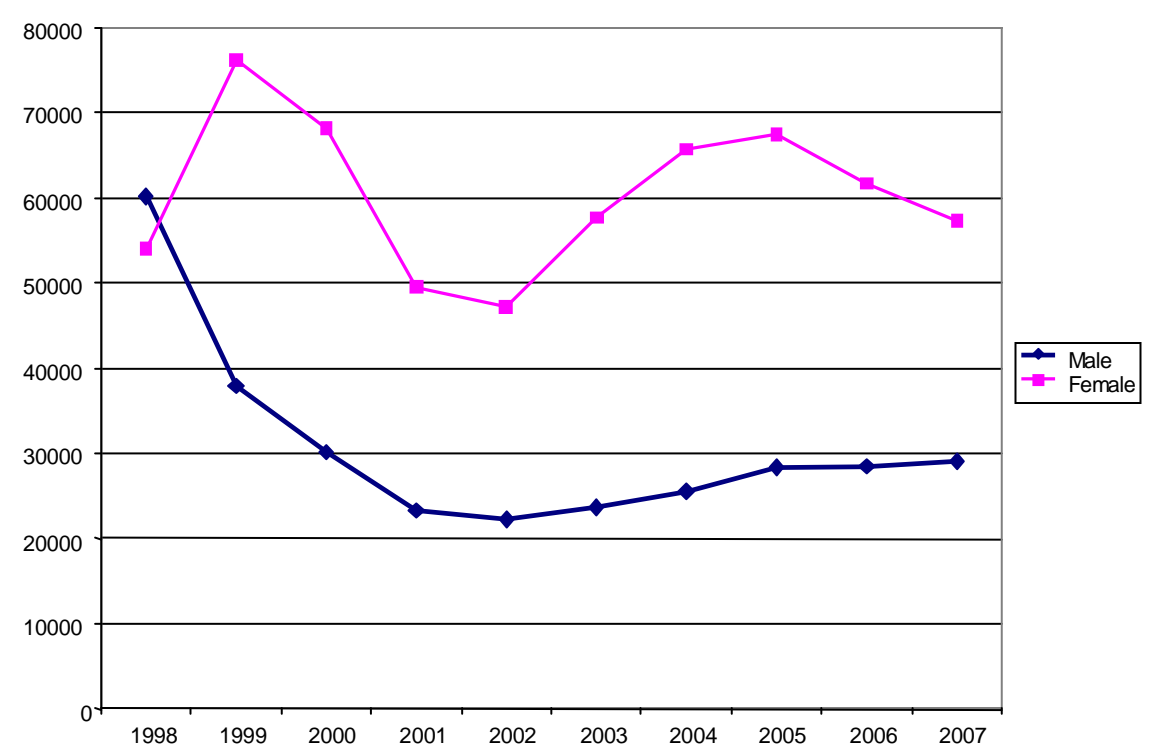

SOURCE: Council of Labor Affairs (2008) - “May 2008 Month book of Labor Statistics - Table 12-5 Foreign Workers by Nationality and Sex." Available at http://statdb.cla.gov. $\mathrm{tw} / \mathrm{html} / \mathrm{mon} / \mathrm{monehidx} 12 . \mathrm{htm}$, accessed on 6 June 2008.

The Taiwanese media reinforce the "otherness" of foreign laborers (Lin, 1999; Wang, 2005). Newspapers and other media portray Filipino laborers and other migrants as dirty, disease-ridden, and transmitters of moral and social disorder (Lin, 1999). The majority of studies on imported labor have focused on domestic workers as they are often the most ill-treated and abused class of migrants (Cheng, 1996; Parre as, 2001; Ciceri, 2003; Kung, 2003; Lan, 2003; Loveband, 2004). Few studies have focused on the factory laborers (Tseng, 2007); yet, over fifty-percent of laborers in Taiwan are employed in manufacturing (Council of Labor Affairs, 2008).

\section{The Labor Recruitment System}

Today there are about 370,000 imported guest workers in Taiwan (Council of Labor Affairs, 2008). Other than the dynamics of push factors in countries of origin and the pull or demand factors in Taiwan, state agencies and the 
migration industry play an important role in facilitating the transfer of labor from source countries such as the Philippines to Taiwan.

The system of overseas placement from the Philippines is highly organized and bureaucratized. It is overseen by an inter-agency committee including the Philippine Overseas Employment Administration (POEA), the Overseas Workers Welfare Administration (OWWA), and the Bureau of Immigration (BI), and governed by the Migrant Workers and Overseas Filipinos Act of 1995. Martin (1993) explains that "private Filipino recruiters go abroad to find jobs for Filipinos to fill, get the Philippine government to approve the contract, and then find Filipino workers to go abroad" (p. 643). Recruitment agencies are profitable business in the Philippines (Martin, Abella and Midgley, 2004). The state legitimizes the necessity of the 'middleman' function in between the applicant and the employer (Sills, 2007; Young, 2004). Though there has been a "placement fee" legally set by the POEA that allowed recruiters to charge one month's salary, reports indicate that OFWs pay up to PHP100,000 pesos to placement agencies - over five times the legal fee (Mission for Migrant Workers, 2008). While in Taiwan, employees pay a labor broker an additional monthly fee to maintain legal status and paperwork. Dormitory and food fees are also mandatory (Tierney, 2007).

Workers are required to provide a background check or "certificate of good conduct" from their homeland (Lee and Wang, 1996). They must submit a medical exam including tests for HIV and other STDs, parasites, tuberculosis, pneumonia and other communicable diseases (Lee and Wang, 1996). Medical checks are required before departure to Taiwan, as well as biannual check-ups while residing in Taiwan. Until 2002, medical checks also included mandatory pregnancy tests to limit births to foreign mothers while in Taiwan (Council of Labor Affairs, 2006); women found to be pregnant today are still sent home immediately. Workers may not gather or form unions and may not participate in collective action. Except under very special conditions and approved by the Council of Labor Affairs (CLA) workers may not change employers. In general, workers have no voice in the terms of their work contract. Contracts are negotiated between the two governments, the Manila Economic and Cultural Office (for the Philippines) and the Council of Labor Affairs (for Taiwan) (Sills, 2007; Young, 2004).

As a means of controlling permanent residency, governmental agencies restrict visas and limit employment contracts. Foreign guest workers in Taiwan may stay up to three years, after which they must return to their home countries. As of mid-2007, a new policy allows foreign workers to reapply for return trips for up to nine years total in their lifetime (Migration News, 2007). There are no provisions for changing visa status without 
returning to the home country. Like other labor-importing countries in Asia, labor migration to Taiwan is intended to be temporary; family reunification and permanent settlement are not allowed.

This recruitment system ultimately has the effect of narrowing the labor pool and awarding the best contracts to those who can pay the most. Young (2004) argues that the accumulation of fees excludes poorer applicants. In addition to the frustration incurred in enduring bureaucratic red tape, middle men and mounting fees, applicants for overseas work must be attractive to potential employer, thereby refashioning their personas as docile hard workers - ideal qualities of guest workers (Young, 2004).

\section{Feminized Migration}

Most of the participants in this study were female. The incorporation of the gendered nature of the migrant experience is a significant development in the migration literature. As Tyner (1999:672) notes, this is more than simply an acknowledgement that women are migrating for work, but an understanding of the "ways that society regulates human interaction and allocates resources differentially, based on socially constructed norms of masculinity and femininity".

In an integrative approach to migration theories, Oishi (2005) proposes that the international migration of women can be examined at the macrolevels of the state, the micro-level of individuals and the meso-level of society. Together, state policies on the emigration of women, the global economy, and the micro-level power of women in the sending country shape the landscape of female emigration in Asian countries such as the Philippines (Oishi, 2005). The household theory of labor migration highlights that labor migration is a strategy to maximize family income (Massey et al., 1993; Semyonov and Gorodzeisky, 2005; Young, 2004). Zontini (2004) argues that women specifically migrate with the goal of providing for family, starting a family business, building a house or sending children to college. The network theory contributes the role of social networks in providing resources for migration (Massey et., 1993). Female migrants thus challenge the social structure as transnational spaces are transformed into gendered spaces, changing social and gender relations (Danneker, 2005). In the Philippines, the family structure and gender roles are reconfigured, with men being left behind and women migrating to become the breadwinners (Asis, 1995; Asis et al., 2004; Zontini, 2004). Migrant women introduce new gender practices in local contexts, potentially altering the dominant perspectives on the role of women (Danneker, 2005).

On the one hand, women gain the opportunity to work abroad, but on the other hand, their integration in the global labor market also renders 
them vulnerable to abuses and exploitative practices. Prior to migration, exorbitant placement fees may lead them into a situation of debt bondage (Villalba, 2002). In addition, traditional gender roles subordinate women to men, resulting in gender-neutral policies that ignore women's special experiences and needs (Piper, 2006). Migrant women may be statistically invisible, in part due to the undocumented nature of some of their work, including sex work or drug trafficking (Piper, 2006). Because most female migrants are in domestic work, they are not protected by national labor laws, since the home is not defined as a workplace (Piper, 2004).

Filipino women recruited to work in the factories of Taiwan comprise skilled, highly educated young women who have been forced to accept lowstatus positions with inadequate pay, few benefits, and no advancement opportunities (Loveband, 2004; Piper, 2004). They are part of the global labor market which, according to the ILO, which employs nearly 66 million individuals in some 3,500 EPZs (Boyenge, 2007). Many manufacturers in neoliberal "free trade zones" prefer the "nimble fingers," low costs and "docility" of women (Elson and Pearson, 1981:90, 98, 95). ${ }^{1}$

\section{Taiwan as a Country of Destination}

Following the legalization of importing guest workers to Taiwan, the growing population of foreign workers induced fear in the native Taiwanese population who felt guest workers would bring with them social and health problems and a desire to settle permanently in Taiwan. Xenophobic attitudes towards foreigners and essentialist stereotypes of guest workers have been well-documented (Law, 2006; Loveband, 2004; Wang, 2005). The media has portrayed migrants as violent, uneducated, and responsible for "stealing" jobs from the Taiwanese (Wang, 2005). Fear of social and health problems brought by foreign guest workers lead to mandatory background checks for 'good conduct' and health screenings (Sills, 2007). Filipinos are also seen as coming from an inferior culture (Wang, 2005). Foreign workers are assumed to be poor, uneducated, and desperate for work (Young, 2004). Like the popular media, labor brokers and employers reinforce stereotypes by marketing workers on essentialist qualities. Employers construct boundaries between ' $u$ ' and 'them', reinforcing a sense of otherness (Cheng, 2004; Lan, 2003). A process of ethnicization develops in which these constructed 'truths' by employers and government agencies become accepted perceived

\footnotetext{
${ }^{1}$ The less educated, older Filipinas fair worse. In Taiwan they are trapped into jobs as domestic workers or caretakers for invalids. Isolated in a foreign household, working six or seven days a week with no overtime and a very meager salary, they have few opportunities to socialize with other OFWs (Ciceri, 2003).
} 
'natural' abilities (Loveband, 2004). Brokers, employers and workers seem to accept that the differences based on stereotypes are true, further alienating the groups.

\section{Methodology}

This ethnographic project involved two trips to Taiwan: in 2003 for eight months and again in 2007 for two months. The study was conducted in Nantze (alternately Nanzih or Nanzu). This location was selected because it is host to one of the oldest EPZs in Taiwan with a large Filipino population. A variety of data collection techniques were used: surveys, interviews, direct observations, participation in activities as a peripheral group member of the local Catholic parish, formal and informal interviews with participants, administration of a modified Twenty Statements Test (TST), and video and photographic documentation. ${ }^{2}$ Interviews were conducted with OFWs, NGO representatives, governmental officials, clergy and scholars (56 such interviews were carried out in 2003, and 25 in 2007). Interviews lasted from one to two hours and covered the participants' educational and economic background, labor history, family structure, migration history (including family members' migrations), labor and social experiences in Taiwan, and plans for the future. Participants selected pseudonyms to protect their identity which were subsequently used in all transcriptions and publications. This paper reports on data from the TST (collected in 2003) and ethnographic surveys (collected in 2003 and 2007).

\section{Twenty Statements Test}

The Twenty Statements Test (TST) was administered in 2003 to 32 OFWs ( 24 females, 8 males), followed by interviews which elaborated on changes they experienced that they attributed to their migration to Taiwan. Initially, OFWs were recruited as volunteers from the congregations of local churches in the Nantze area and from a snowball sample thereafter.

Kuhn and McPartland's Twenty Statements Test (1954) (sometimes referred to as the TST, the Who am I? test, or WAI test) has been applied in studies such as the investigation of women's "general self-attitudes"(Falk and Sonenfeld, 1974), the ethnic identity of adolescents (Verkuyten, 1991),

\footnotetext{
${ }^{2}$ A third of participants photographically documented their lives with film or digital cameras provided by the study. A dissertation, several articles, a website, and a short documentary entitled "Filipino Labor Migrants in Taiwan: Caretakers, Nursing Aides, and Domestic Workers" have been produced from the project thus far. An additional documentary on factory workers is forthcoming.
} 
ethnic identity and self-esteem (Lay and Verkuyten, 1999), and development of a cultural identity among adolescent immigrants (Sapru, 2006). It has also been used in numerous cross-cultural studies on identity (Church, 2001; Kühnen, Hannover and Schubert, 2001; Poortinga and Van Hemert, 2001; Watkins and Gerong, 1997; Hong, Ip, Chi-yue, Morris and Menon, 2001).

In their original study, Kuhn and McPartland (1954) noted that not all of their respondents would complete a full twenty statements about themselves. According to Carpenter and Meade-Pruitt (Carpenter and MeadePruitt, 2008)," research has shown the TST may be more effective with as few as seven or 10 responses." For this study, the TST was modified and shortened. OFWs were provided a form on which they were given an opportunity to respond to the question "Who am I?" first with ten "I am..." statements (now) and then with ten context dependent "In the Philippines, I was..." statements (before). It should be noted that not all participants provided a full 20 statements. The TST was administered to 32 individuals. However, four of the respondents misinterpreted the directions, writing instead a short autobiography rather than statements beginning with "I am" and "I was." Thus, twenty-eight of the thirty-two tests were used for this analysis (20 females, eight males). In all, there were 246 now statements that were coded and 205 before statements.

\section{Ethnographic Surveys}

Two ethnographic surveys ${ }^{3}$ were conducted to gather general, though not generalizable, information about Filipino factory workers (2003: N=389; 2007: $\mathrm{N}=526$ ).

A 101-questionnaire was administered in May 2003 to OFWs, a majority of whom were recruited from a single celebration of the Sunday mass at St. Joseph the Worker Parish in Nantze, Taiwan $(\mathrm{N}=355)$. This convenience sample of Catholic members of the parish represented the single largest gathering of Filipino workers in Nantze. We also included a non-random sample of respondents from other churches and dorms for comparative purposes. A total of 34 respondents were recruited from the Higher Ground Free Methodist Church in Nantze (the women's Bible study group), Jesus is Lord Fellowship in Kang Shan, and non-church members from Green House women's dormitory.

The second survey was administered in July 2007, also at St. Josesph's in Nantze, during both the morning and evening masses. A total of 526

\footnotetext{
${ }^{3}$ Following methods discussed in LeCompte and Schensul (1999).
} 
respondents completed the self-administered questionnaire. The brief questionnaire consisted of 36 items focusing on background information, international work history, employment-related issues, ties to homeland, emotional well-being, and remittances. There were two open-ended questions soliciting comments about experiences in Taiwan and future plans after returning to the Philippines. Open-ended comments were classified and coded according to recurring themes using respondents' words. Codes were grouped under four themes or parent codes: issues of adjustment/ acculturation; interethnic relations and discrimination; work-related problems; and reasons for migrating. This coding scheme allowed overlap among codes as some comments fit in more than one theme.

\section{Background Information}

Nantze is home to one of Taiwan's oldest and most well-established EPZs, a research and manufacturing park with more than 90 factories (Export Processing Zone Administration 2002; Export Processing Zone Administration 2007). It is situated on the outskirts of Kaohsiung, Taiwan's second largest and most industrial city. The Nantze EPZ (NEPZ) was built in 1969 as Taiwan's second EPZ and has been host to a number of export-related products: textiles and apparel, plastics, fabricated metals, wood, and bamboo products. Today, NEPZ is a production zone for high-tech industries engaged in manufacturing as well as research and development. Nearly half of the manufacturing firms in the zone (47.7 percent) is in electronics and computers (Export Processing Zone Administration, 2007). The 90hectare walled campus is surrounded by apartments and dormitories for foreign guest workers. There is also a thriving business district with shops catering to the needs of OFWs: Internet cafes, Filipino lunch counters (often run by Filipina wives of Taiwanese men), shipping centers, money transfer companies, and small shops selling consumable goods imported from the Philippines.

For background information of the OFWs in Nantze, we draw on demographic data gathered from the 2003 and 2007 surveys. The profile of OFWs in both surveys is summarized in Table 1. According to the surveys, the OFWs in Nantze were mostly factory workers and were overwhelmingly female. The predominance of women respondents is a reflection of the hiring policy of factories, which prefer to hire women, considered best for the delicate work of electronics manufacturing. The small minority of males were contract engineers, workers from nearby Kangshan, which has light industrial manufacturers, and a few ship builders from the Kaohsiung Export Processing Zone (KEPZ). Respondents were mostly unmarried females in their mid- to late twenties (mean 28 years in both 2003 and 2007). 
TABLE 1

Characteristics of Respondents, 2003 And 2007 SuRVeys

\begin{tabular}{lrr}
\hline Characteristic & 2003 & 2007 \\
\hline \% female & 90 & 88 \\
Age (mean) & 28 & 28 \\
Age range & $19-44$ & $21-53$ \\
\% never married & 67 & 66 \\
\% with children & 19 & 21 \\
\% single parents of those with children & 22 & 20 \\
\% first trip as OFW & 47 & 56 \\
\% ever worked in another country & 13 & 10 \\
\% completed college/university degree & 89 & 91 \\
N & 389 & 526 \\
\hline
\end{tabular}

Around a fifth reported that they had children, and a fifth of those were single parents. About half (47 percent in 2003 and 56 percent in 2007) were on their first trip to Taiwan. Most (90 percent in 2003 and 88 percent in 2007) reported completing a college or a university degree.

\section{Personal Reasons for Migrating}

TST participants expressed a variety of personal reasons for migration (Table 2). Economic necessity - due to lack of job opportunities, low wages, or poor standard ogf living - was often combined with other motivations. For example, the death of a spouse, separation, or a break up with a romantic partner motivated some to seek a dramatic change in their lives. Many were motivated by wanting to be near friends who were also going to Taiwan for work. The desire to migrate one day to a more developed country prompted some to work in Taiwan as a first step, saving money for onward migration to Europe, Canada or the USA. Others were searching for work experience,

TABLE 2

ReASONS FOR Migration*

\begin{tabular}{lr}
\hline Reason & N \\
\hline Economic Necessity & 23 \\
Social Ties (friends \& family) & 9 \\
Sense of Obligation & 6 \\
Death or Breakup & 4 \\
Adventure & 3 \\
Other & 9 \\
\hline
\end{tabular}

NotE: *Based on multiple reasons provided by TST participants 
adventure or excitement in a foreign country (e.g., Asis 2002). Finally, a number of participants found that they could not really articulate a reason leaving the explanation to simple chance, fate or "God's will."

\section{Content Analysis of Self-Concept Statements}

Because of its flexibility and open-ended nature, there have been many approaches to the coding and analysis of the TST over the past 50 years. Kuhn and McPartland's (1954) approach was to classify statements as consensual or subconsensual. Consensual statements are "socially anchored" (p. 73). As McPhail and Tucker (1972) explain, "consensual statements are those which refer to groups and classes whose limits and conditions of membership are matters of common knowledge and which require no further interpretation by the respondent to be precise or to place him relative to other people" (p.330). Examples may be "I am a male" or "I am a teacher." Subconsensual statements are related to the individual without reference to position within society (Kuhn and McPartland, 1954; McPhail and Tucker, 1972). For example "I am lazy" or "I am a good student" are coded as subconsensual statements.

Some researchers have taken to using purely content analysis approaches, grounding the coding in the statements themselves. Using this approach, one study among immigrant youth outlined 18 code categories linked to ethnic identity "such as language, body image, personality, tastes, competence, occupation and school"(Clark and Flores, 2001:76). Others have developed structured coding schemes that are more inclusive than the consensual/subconsensual dichotomy, yet not as expansive as a grounded content analysis. The code categories physical, social, attributive, global and other have been used in a number of recent studies (Antonelli, Rubini and Fassone, 2000; Cousins, 1989; Kanagawa, Cross and Markus, 2001).

This study used a similar scheme. Statements were categorized by the researchers as being: Personality Traits (PT), Social Roles (SR), Physical Descriptions (PD) and Other (Other). A series of subcodes were grounded in the responses (Table 3). Personality Traits were judged to be positive, negative or neutral. They included such statements as: "I am... independent," "I am... a hardworking type of person, "or "I was... very lazy." Social Roles included ethnic/national statements such as "I am... a Philippine citizen," religious declarations like, "I am... a member of the family of God," to relational roles as, "I am... a mother of two kids." Physical Descriptions included a single case of physical condition in which the participant declared, "I was... not healthy." Other categories, included age or birth date, name, time spent in Taiwan, work-related statements (e.g., "We don't have any O.T."), and existential statements (e.g., "I am... nobody"). Some state- 
TABLE 3

Summary of Coded Statements by Subcode

\begin{tabular}{|c|c|c|c|c|}
\hline \multirow[t]{2}{*}{ SubCodes } & \multicolumn{2}{|c|}{ During Migration } & \multicolumn{2}{|c|}{ Before Migration } \\
\hline & $N$ & Percent & $N$ & Percent \\
\hline \multicolumn{5}{|l|}{ Personality Traits (PT) \& } \\
\hline Physical Descriptions (PD) & 114 & 46.3 & 89 & 43.4 \\
\hline PD - Negative & 0 & 0.0 & 1 & 1.1 \\
\hline PT - Negative & 19 & 16.7 & 44 & 49.4 \\
\hline PT - Neutral & 19 & 16.7 & 13 & 14.6 \\
\hline PT - Positive & 76 & 66.7 & 31 & 34.8 \\
\hline Sub Total & 114 & 100.0 & 89 & 100.0 \\
\hline Social Roles (SR) & 104 & 42.3 & 104 & 50.7 \\
\hline SR - Ethnicity/Nationality & 11 & 10.6 & 0 & 0.0 \\
\hline SR - Occupational & 20 & 19.2 & 22 & 21.2 \\
\hline SR - Relational & 33 & 31.7 & 54 & 51.9 \\
\hline SR - Religious & 36 & 34.6 & 15 & 14.4 \\
\hline SR - Activity & 4 & 3.8 & 6 & 5.8 \\
\hline SR - Non-Religious & 0 & 0.0 & 7 & 6.7 \\
\hline Sub Total & 104 & 100.0 & 104 & 100.0 \\
\hline Other Statements (Other) & 28 & 11.4 & 12 & 5.9 \\
\hline Other-Name & 6 & 21.4 & 1 & 8.3 \\
\hline Other - Age & 4 & 14.3 & 0 & 0.0 \\
\hline Other - Geographic & 1 & 3.6 & 2 & 16.7 \\
\hline Other - Time in Taiwan & 2 & 7.1 & 0 & 0.0 \\
\hline Other - Work Related & 8 & 28.6 & 0 & 0.0 \\
\hline Other - Existential & 7 & 25.0 & 9 & 75.0 \\
\hline Sub Total & 28 & 100.0 & 12 & 100.0 \\
\hline Total & 246 & 100.0 & 205 & 100.0 \\
\hline
\end{tabular}

ments such as "I am a Filipina working in a Taiwanese factory" could be coded within multiple categories (in this case SR - Ethnic/national and SR - Occupational).These codes were first analyzed in the aggregate, followed by an individual-level analysis that looked into the difference between before (in the Philippines) and during migration (in Taiwan) statements. 


\section{Personality Traits}

Statements coded as Personality Traits (PT) or Physical Descriptions (PD) increased from 43.4 percent when respondents were in the Philippines (or "before" statements) to 46.3 percent when respondents were in Taiwan (or "now" statements). More importantly, before migration, nearly half (49.4 percent) of personality traits were indicative of a negative self-concept, including such statements as: I was... very lazy; I was... a cruel student during college; I was... fickle-minded; I was... [an] irresponsible daughter; and I was... unfaithful friend. Two-thirds (66.7 percent) of the PT traits statements during migration were coded as positive and they also indicate a shift toward greater independence, as suggested by statements such as: I am... a strong woman; I am... matured in decision making; I am... independent; I am... hardworking; I am... stronger than I had been before; I am ...more patient now; and I am... responsible.

\section{Social Roles}

Before migration, the participants' self-concept was largely embedded within the context of social roles, particularly family relationships. Half (50.7 percent) of all "before" statements were coded as Social Roles (SR). In all, 51.9 percent of statements regarding social roles, or roughly a quarter of all "before" statements, were associated with relational roles. Examples included: I was... the older brother in our family; I was... the eldest daughter; I was a responsible father, husband and son; I was... a mother; and I was ... helping my family. In contrast, only 42.3 percent of "now" statements were related to social roles. Relational statements decreased to 31.7 percent of social role statements during migration and were often related to support that the migrant was providing family members back home: I am... doing everything for my parents and brother and sister; "I am... supporting financially my sister's schooling;" and "I am... sending money to my family, [but] it's too little."

As social roles became less an everyday part of migrant identity, religion and ethnic/national identity became more salient. Some 10.6 percent of social role statements during migration indicated an awareness of ethnic/national identity; no such statements were recorded before migration. Importantly, 63 percent of these ethnic/national identity statements were among the first three statements provided by the migrants. Pride in national origin, citizenship and being an OFW (coded both as an occupational and cultural role) suggest a redefining of self in nationalistic terms. These were indicated by such statements as: I am... a Filipina working in Taiwan as [an] OFW; I am... a native Philippine citizen; I am... [a] foreign 
worker here in Taiwan; and I am... a pure Filipina. We argued that statements such as these would not have been as common within the context of the Philippines where regional identity would be more salient.

More than 35 percent of SR statements were religious in nature, which may be a sampling artifact - TST participants were recruited from religious institutions. In addition, the statements do show that religion has assumed importance for OFWs in Taiwan. Before migration, 13 percent of SR statements were religious in nature and another six percent of the statements indicated that the migrants were not religious or much less religious (including not being involved in church activities) prior to migration. The latter was indicated by such statements as: I was... not [a] church volunteer; I was... not too close to God; I was...agnostic; and I was...not so active in religious activities. In Taiwan, the same individuals indicated that they had experienced a religious conversion (in particular those who were part of the charismatic ElShaddai movement ${ }^{4}$ or the evangelical Christian churches) or had become much more committed to their social roles within the church. The shift is suggested by statements such as:: I am... a born again Christian; I am... a member of a family of God; and I am... a God fearing person.

\section{"Other" Statements}

The majority of statements coded as other situated the migrant within her current environment or spoke of the "public self" (i.e., the basic information that we usually provide when asked who we are-e.g., name, age, residence, etc.). When asked to answer "who am I?" six of the respondents began with their names. Names were coded as social roles (Tan, 2003), but we did not interpret this as an indication of the individual's self-concept. Eight workrelated statements surfaced, but they were more labor grievances than statements of identity. In all, 5.9 percent of pre-migration and 11.4 percent of during migration statements were coded as other.

\section{Gendered Transitions in Self Concept}

In the aggregate-level analysis of statements, we began to see a shift in the migrant's self-concept from a collective sense of self (particularly as a family member) to a more independent and individualistic self as a community member. We further analyzed this transition by way of an individual-level

\footnotetext{
${ }^{4}$ A popular charismatic prayers group within the Catholic Church in the Philippines. It was started by Brother Mike Velarde in Manila in 1984. The movement has spread to overseas Filipino communities in different parts of the world.
} 
TABLE 4

Results of Individual Analysis of Coded Statements by Gender

\begin{tabular}{lrrrrrrrrr}
\hline & \multicolumn{2}{c}{ Increased } & \multicolumn{2}{c}{ Same } & \multicolumn{2}{c}{ Decreased } & \multicolumn{2}{c}{ Difference } \\
\cline { 2 - 10 } \multicolumn{1}{c}{ Code Category } & M & F & M & F & M & F & M & F \\
\hline Ethnicity/Nationality & 6 & 3 & 2 & 17 & 0 & 0 & 6 & 3 \\
Positive Personality Traits & 4 & 13 & 2 & 3 & 2 & 4 & 2 & 9 \\
Occupational Social Roles & 3 & 4 & 2 & 12 & 3 & 4 & 0 & 0 \\
Relational Social Roles & 4 & 4 & 1 & 7 & 3 & 9 & 1 & -5 \\
Religious Social Roles & 4 & 12 & 4 & 8 & 0 & 0 & 4 & 12 \\
Other & 5 & 6 & 1 & 13 & 2 & 1 & 3 & 5 \\
\hline
\end{tabular}

Note: $\mathrm{M}=$ Male; $\mathrm{F}=$ Female

analysis. For this analysis, we compared the during migration (now) segments on the TST against the reflective pre-migration (before) statements. Statements were tallied and for each category of statements, we totaled the number of TST participants which registered an increase, remained the same, or decreased in the statement category during migration. A measure of difference was arrived at by subtracting the decrease from the increase. The summary is presented in Table 4. Tallies are presented for males vs. females in order to see differential outcomes by sex. Given the small number of respondents (eight males, 20 females), we cannot claim any statistical significance. The data, however, may be indicative of the direction of changes in self-concept and how this proceeds for men and women.

Table 4 demonstrates that most female OFWs showed an increase in the number of positive personality trait statements (13 of 20 respondents) and in the number of their religious social roles statements (12 of 20 respondents). They remained constant in the number of their occupational social role statements (12 of 20 respondents) and in their "other" statements (13 of 20 respondents). Women remained constant (seven of 20 respondents) or showed a decrease (nine of 20 respondents) in the number of relational social role statements. Finally, three women referred to ethnic/national identity in their statements.

Males also showed some increase in the number of positive personality trait statements (four of eight respondents), the number of relational social role statements (four of eight respondents), the number of religious social role statements (four of eight respondents) and in their "other" statements (five of eight respondents). Most males also made reference to their ethnic/ national identity (six of eight respondents). They remained relatively constant in the number of occupational social role statements. 
The increase in relational social roles among males may be related to the fact that more male factory workers in Taiwan were married (43.9 percent according to the 2007 survey) than female factory workers (16.9 percent) and were also more likely to have children ( 38.3 percent of men compared to 18.4 percent of women based on the 2007 survey). In the interviews, several men explained that, at least in the beginning of their stay, they were enticed to engage in dating, given the presence of many single young Filipinas. Some indicated that they had dated several women simultaneously, including those who were already married. Joshua, for example, admitted that in his first six months in Taiwan, he spent all of his money dating many women. Six months into his stay, however, his wife gave birth and he experienced a religious conversion. Nearing the end of his three-year contract at the time interview, he explained that all of his money now was sent to his wife and son and he had become recommitted to her. Much of his self-concept revolved around this social role of father, husband and provider for his family.

\section{Becoming an $O F W$}

In becoming an OFW, the migrant experiences a shift in identity. This change includes a more positive self-concept as the femalemigrant becomes independent of the family. Relational social roles, as defined by the family, though no less important to the OFW in the context of Taiwan, undergo a change from "dependent of" to "provider for" as they represent an important source of family income. This observation may also be due in part to the age of many of the workers, as the majority were recent college graduates and, until their migration, had lived in multi-generational households. Once "on their own" in Taiwan they had more time for themselves and they made connections independent of the family. In this way, they developed greater autonomy and a stronger, more individualistic sense of self. We argue that even the loss of status in taking a labor position in Taiwanese factories has the outcome of helping the OFW become mature, patient and humble.

Melanie, or "Lanie," aged 23 provides a good example of this transition as she recognized the shift to more autonomy. She was the youngest of five and describes herself as having been naughty, secretive and "attached with material things" when she was still in the Philippines. She graduated with a major in Mass Communications in Broadcasting but was out of work, or "vacant" as she put it, for a year after graduating. She learned about a job opening in Taiwan through a neighbor and decided to come to Taiwan because of the salary and the good reputation of the company. At the time of interview, she had been working in Taiwan for three years. Lanie 
explained that she had become more independent and thrifty while working as an OFW. She attributed at least part of her growth to her involvement in the charismatic El Shaddai prayer group. She became involved in many of the church activities and even took a leadership role in El Shaddai. She explained that though she was planning to return at the end of her two year contract, she signed on for another year because of these church commitments.

Similarly, Josephine, or sometimes just "Jo," exemplified the selfreliance that develops from being far from those on whom you depend. She was the youngest of six and was only nineteen years old when she became an OFW using fake credentials to get the placement. After completing college, she decided to work in Taiwan because she did not want to "get stuck" in her town. Although she did not plan nor expect to go abroad, she decided to follow her college classmates to Taiwan. She also attributed the decision, at least in part, to the fact that her parents were strict and she wanted her freedom. She said that she became more mature as a result of becoming an OFW: “...my mind has broadened. My outlook on life has, I became mature. It's different now. I'm thinking of different things now. It's like, it's more advanced, ... unlike before, when I hadn't experienced being alone."

On the other hand, OFWs were also cognizant of the loss of social class that occurs while abroad. Caroline came to Taiwan, six years after graduating from college with a BA in History and a minor in Anthropology. She decided to work in Taiwan because she could not maintain a regular job in the Philippines and had little money. While working in the quality control lab doing failure analysis of circuit boards, she said she had become much more responsible. She explained that the compulsory curfew in her dorm, factory restrictions on personal freedoms, and having more friends who were church-goers curbed her "naughty" behavior. Yet, the experience of being an OFW also carried an element of humility and loss of status: "...you know, one of my friends in the Philippines, number five in the bar exam, while me, I'm here in Taiwan as a factory worker. I didn't, actually, I didn't tell them. That I'm here.... because they don't, they don't, they don't expect me to work here as a factory worker."

\section{Becoming a Filipino}

In the 2003 survey, we posed questions regarding interpersonal (specific) and intergroup (generalized) relations. In the interpersonal relations questions, respondents were asked to list their five closest friends, their best friend, their favorite coworker, the person they most admire and romantic partner. They were then told to indicate the nationality of these people. As 
TABLE 5

Percentage Distribution of OFWs' Preferences: Interpersonal Relations

\begin{tabular}{lcccc}
\hline & Filipino & Taiwanese & American & Other Nationality \\
\hline Friend \#1 & 98 & 2 & 0 & 0 \\
Best friend & 98 & 0 & 2 & 0 \\
Romantic partner & 92 & 1 & 6 & 1 \\
Favorite co-worker & 91 & 5 & 2 & 1 \\
Friend \#4 & 88 & 3 & 2 & 7 \\
Friend \#3 & 85 & 7 & 6 & 2 \\
Friend \#2 & 83 & 9 & 7 & 1 \\
Person most admired & 81 & 3 & 14 & 2 \\
\hline
\end{tabular}

expected, OFWs showed the most affinity for co-Filipinos in their interpersonal relations (Table 5).

In 2003, we also asked questions regarding intergroup relations. Respondents were asked to indicate on a five-point Likert scale (strongly agree to strongly disagree) their affinity for the different nationalities with whom they may live and work while in Taiwan. Not surprisingly they again showed the greatest tie to co-ethnics and much weaker ties in relation to their host and other migrant workers in Taiwan (Table 6).

In the 2007 survey, respondents described the discrimination and alienation they had experienced. Yet, only 17 percent of all respondents $(\mathrm{N}=529)$ agreed or strongly agreed that they had problems with Taiwanese people. Most expressed neither a strong liking nor dislike of Taiwanese, but their comments underscored the difficulties they were going through:

TABLE 6

OFWs' Mean Scores on Measures of Intergroup Relations

\begin{tabular}{lc}
\hline Statement & Mean \\
\hline I like Filipinos & 4.0 \\
I have a good relationship with Filipinos & 4.0 \\
I like Taiwanese & 3.0 \\
I have a good relationship with Taiwanese & 3.0 \\
I like Thais & 2.2 \\
I have a good relationship with Thais & 2.1 \\
I like Indonesians & 2.2 \\
I have a good relationship with Indonesians & 2.1 \\
\hline
\end{tabular}


Foreign people look on Filipinos so low and bad. You really feel the discrimination.

[It is so] hard to be an OFW, I never expected to experience how hard it is to earn [a] living. Taiwanese people may be good sometimes but most of the time they treat Filipinos so cruel...I'm praying that someday they will treat us humanely, not like they want us to be treated like animals.

Being an OFW is harder than I thought, language barrier, culture and working environment is far different from my country...

As an OFW is not easy because I need to adjust. [The] Philippines and Taiwan [are] so different....

As a result of their temporary status, with no option for long-term residence, socially isolated and segregated from the Taiwanese population and experiencing discrimination in work and social settings, OFWs are left with only the option of social creativity in "becoming" Filipino. They cannot rally against the dominant ethic/national group and demand rights due to the fact that they would be deported. They cannot assimilate into the dominant society. Given marginal interaction with the local population, they tend to turn to other Filipinos. They celebrate Filipino holidays (77 percent of survey respondents in 2003 observed a Filipino holiday while in Taiwan). In the enclave around NEPZ, they consume Filipino food and purchase familiar Pinoy (i.e., Filipino) products.

This celebration of nationality was most apparent in TST statements of males who were most removed from the security of the enclave, residing in a town about $10 \mathrm{~km}$ from Nantze. In the follow-up interviews, these men spoke of their adherence to Philippine culture, as well as the duties and obligations of being Filipino. Three interview cases are presented as evidence of the shift in self-concept to a national Filipino identity.

Edwin, 27 years old, was the only male OFW who had been in a relationship with a Taiwanese woman. He quit after one year of college because of lack of funds. In 1997, he joined his brother in Taiwan, who told him of the good pay. Asked about being a Filipino in Taiwan, he replied, "I feel like I have a responsibility for my country so wherever I go I have to think that I'm a Filipino. I have to put it in my mind." When asked to elaborate on what it is to be Filipino, he said, "... it's loving your family, our own culture, [and] yeah speaking Filipino [Tagalog]."

OFWs are often hailed by the Philippine government as "modern day heroes" for their valuable economic support. In recognition for their contributions, select workers are annually given an award from the POEA 
presented by the Philippine president.PresidentGloria Macapagal-Arroyo's message to OFWs in Taiwan, which was published in Taipei Times (12 June 2002), illustrates the government's attempt to include OFWs in the nation's celebrations and their special responsibility:

My most cordial greetings to my countrymen in Taiwan on the celebration of the 104th Philippine Independence Day. As Filipinos living in a foreign land, you have the distinct role of serving as our country's ambassadors of goodwill in your host country. You are called upon to serve as agents of our country in fostering stronger, cultural, political and economic ties between our country and Taiwan.

Jin resonated with this nationalistic sentiment. He was on his second trip to Taiwan working as a forklift operator for a metal fastener manufacturer. He was a Computer Science graduate and was employed as a data processor for bank in the Philippines. His monthly income of PHP5,000 was not enough to support his wife and young son. The prospect of earning three-fold in Taiwan compelled him to leave the Philippines. In Taiwan, he was saving for his son's education and plans to open a stall in a fish market when he returns. Asked to elaborate on his TST statement about being a Filipino worker, he explained, "it's like, it's just like, I'm working for my country and working family."

The rhetoric of President Macapagal-Arroyo was also reflected by Lody. Lody had been in Taiwan for a little over two and a half years at the time of interview. He was there to help support his three children and to raise more capital for his failing business back home. It was his first trip to Taiwan, but he had worked previously in a factory in Saudi Arabia for eight years. Due to the weak economy, he explained that he could not make enough money from his business to support his family. He also viewed working abroad and remitting funds as a kind of civic duty:

So, as a Filipino, I think that is, that is the only [way] I can help our country. By going abroad. Because, [I] earn money here, in [anlother country, and [I] send money to [the] Philippines. That is the, that is, that is the way I can help our country... if you are an OFW, you are [a] hero... [OFWs] are heroes of the... the Filipino[s], [By] earning money in Taiwan and then sending money to the Philippines. So it [also] helps your family... the president says the OFW is the hero of the country. 


\section{Conclusions}

We have shown that OFWs in Taiwan experience a shift in self as social roles and relationships are renegotiated. A stronger sense of self confidence emerges, particularly among the female OFWs. Prior to the migration experience, their self-concept was embedded in their social roles in the family. This deep sense of obligation to the family became the catalyst for migration for most migrants (male or female) and continues to play an influential role in the level of remittances to the homeland. Although identity was previously rooted in the collectivism of the family, the migration experience itself has led to a more salient individualized self among the women. The analysis of TST statements analyzed at the individual level revealed that a greater proportion of the female migrants developed a more positive self-concept and that their social relations became less salient in defining who they were in Taiwan. Becoming an OFW in Taiwan is arduous and demanding. The forced independence from family and the shift in roles to that of economic "provider" are reflected in the many statements like, "I am doing everything for my parents, brother and sister," and "I am financially supporting my sister's schooling." This transition from dependent to patron of the family was especially central to the development of a more positive self-concept among Filipina migrants. Men, while also improving in self-concept, demonstrated a more noticeable shift in their ethnic or national identity as a result of being further isolated (geographically) from the Filipino community. The men seemed to resonate more with the rhetoric of the Philippine government that OFWs are "heroes" by the sacrifices they make to support their families in the Philippines.

Lan (2003) notes that "after more than a decade of recruiting migrant workers, local Taiwanese have gradually accepted their presence as long as they remain marginal spatially and socially." National identity, racial characteristics and nationally based class differences are the lines on which boundaries are drawn (Cheng, 2004). Boundary work becomes a strategy and practice used to create, maintain, and reinforce cultural categories. Employers and workers define who they are by organizing themselves along lines of difference (Lan, 2003). By constructing social distance, employers establish and reinforce feelings of superiority; this social distance alienates foreign workers (Cheng, 2004; Lan, 2003). In this context, foreign workers are assigned the label of the out-group. They are treated as the "alien other," and assigned a lesser role in the socially stratified society. The obvious rejection by the Taiwanese community challenges their sense of belonging. Moreover, opportunities for assimilation are greatly limited by the structural constraints of their employment: the governmental policies limiting their mobility, the factory or broker imposed curfews and limitations, and the lack of a "place" within the host society. 
While socially rejecting the foreign workers, the host Taiwanese community does supply economic opportunity that they may not be able to find in the Philippines. This seems to foster among OFWs an attitude of indifference toward the Taiwanese people. There is little to motivate the worker to seek an understanding of the Taiwanese and few opportunities to explore the culture. However, for those living in the vicinity of the EPZs, there is a pull to reaffirm their own ethnic/national heritage, and even nationalistic pride, as the institutions of the immigrant enclave provide a sanctuary from the social isolation of the host community.

Social creativity emerges among OFWs in response to rigid ethnic boundaries, shaped by essentialist stereotypes and geographic and social alienation. Once the group is socially defined, seen as being of geographic origins outside of the host country, and is excluded or marginalized, racial differences come into play, increasing in-group social identity (or 'reactive' ethnic identity) (Ng, 2005; Sanders, 2002). Transnational communities and ethnic networks supply the social goods not available within the host society (Sanders, 2002). As other researchers have found, ethnic enclaves of Filipino workers retain a coherent and culturally based sense of identity centered on a shared Catholic faith (Lindio-McGovern, 2004; Wang, 2005). Lindio-McGovern (2004) and Wang (2005) both found that performance of culture within a religious context was central to maintaining the in-group identity of Filipino workers. Religious mass routinely brought Filipinos together, serving as the only outlet in which Filipinos can gather in large groups. A feeling of "oneness" was created through participation in mass (Lindio-McGovern, 2004). As OFWs focus their free time on the institutions of the enclave, especially religious organizations, ${ }^{5}$ they reaffirm their ethnic/national identity as Filipinos. These institutions provide a way to ameliorate their quality of life and mediate the discrimination they experience in the receiving community. They also provide a transnational space that allows the celebration of homeland culture through the observance of Filipino national holidays, religious festivals, music, dance, language, food and activity groups centered on cultural expression. Essentially, migrants recognize their national unity and become "transnationalized" within the context of exclusion and discrimination.

\footnotetext{
${ }^{5}$ Observational evidence suggests that the dance clubs, bars, and other non-religious social institutions, which also cater to Filipino migrants around the EPZs, provide a place in which they may find refuge from the host society, but not in the numbers that are found in the churches. For example, attendance at the Sunday masses at St. Joseph the Worker parish in Nantze are around 500 to 600 parishioners both at the morning and evening mass.
} 


\section{REFERENCES}

Migration News

2007 "Taiwan: Migrant Policy Evolution," Migration News, 13(3). Available at http:// migration.ucdavis.edu/MN/more.php?id=3307_0_3_0, accessed on 6 June 2008.

Abella, Manolo

1993 "Labor Mobility, Trade and Structural Change: The Philippine Experience," Asian and Pacific Migration Journal, 2(3):249-268

Antonelli, Elena, Vittorio Rubini and Cristina Fassone

2000 "The Self-Concept in Institutionalized and Non-Institutionalized Elderly People," Journal of Environmental Psychology, 20(2):151-164.

Asis, Maruja

2006 "Living With Migration: Experiences of Left-behind Children in the Philippines," Asian Population Studies 2(1):45-67.

2003 "When Men and Women Migrate: Comparing Gendered Migration in Asia." Paper presented at the Division for the Advancement of Women, UN Department of Economic and Social Affairs Consultative Meeting." Migration and Mobility and How This Movement Affects Women," Malmo, Sweden. Available at http://www.un.org/ womenwatch/daw/meetings/consult/CM-Dec03-EP1.pdf, accessed on 6 June 2008.

2002 "From the Life Stories of Filipino Women:Personal and Family Agendas in Migration," Asian and Pacific Migration Journal, 11(1):67-93.

1995 “Overseas Employment and Social Transformation in Source Communities: Findings from the Philippines," Asian and Pacific Migration Journal, 4(2-3):327-346.

Asis, Maruja, Shirlena Huang and Brenda Yeoh

2004 "When the Light of the Home is Abroad: Unskilled Female Migration and the Filipino Family," Singapore Journal of Tropical Geography, 25(2):198-215.

Bagnoli, Anna

2007 "Between Outcast and Outsider:Constructing the Identity of the Foreigner," European Societies, 9:(1):23-44.

Boyenge, Jean-Pierre Singa

2007 ILO Database on Export Processing Zones (Revised). Geneva, Switzerland: International Labour Office.

Carpenter, Sandra and S. Maria Meade-Pruitt

2008 "Does the Twenty Statements Test Elicit Self-Concept Aspects that are Most Descriptive?," World Cultures eJournal, 16(1). Available at http://repositories.cdlib.org/wc/ worldcultures/vol16/iss1/art3, accessed on 6 June 2008.

Chan, Raymond

1999 “Taiwan's Policy Towards Foreign Workers," Journal of Contemporary Asia, 29(3):383400. 
Chang, Ming-Cheng

2003 "Demographic Transition in Taiwan," Journal of Population and Social Security (Population), Supplement to Volume I.

Cheng, Shu-Ju Ada

2004 "Contextual Politics of Difference in Transnational Care: The Rhetoric of Filipina Domestics' Employers in Taiwan," Feminist Review, 77:46-64.

2003 "Rethinking the Globalization of Domestic Service: Foreign Domestics, State Control, and the Politics of Identity in Taiwan," Gender and Society, 17(2):166-186.

1996 "Migrant Women Domestic Workers in Hong Kong, Singapore and Taiwan: A Comparative Analysis," Asian and Pacific Migration Journal, 5(1):141-154.

Church, A. Timothy

2001 "Personality Measurement in Cross-Cultural Perspective," Journal of Personality, 69(1):979-1007.

Ciceri, Bruno

2003 "Taiwan: Land of Dreams and Tears." Paper presented at the 'On the Asian Migration Trail' Seminar, Bangkok, Thailand, 13-15 February.

Clark, Ellen Riojas and Belinda Bustos Flores

2001 "Who Am I? The Social Construction of Ethnic Identity and Self-Perceptions in Latino Preservice Teachers," The Urban Review, 33(2):69-86.

Council of Labor Affairs (CLA)

2008 "May 2008 Month Book of Labor Statistics - Table 12-5 Foreign Workers by Nationality and Sex." Available athttp://statdb.cla.gov.tw/html/mon/monehidx12.htm, accessed on 6 June 2008.

2006 "Report on Protection of The Rights for Foreign Workers in Taiwan." Available at http://www.evta.gov.tw/files/89/engtitle.pdf, accessed on 12 July 2007.

Cousins, Steven D.

1989 "Culture and Self-perception in Japan and the United States," Journal of Personality and Social Psychology, 56(1):124-131.

Creswell, John

1998 Qualitative Inquiry and Research Design: Choosing among Five Traditions. Thousand Oaks, CA: Sage.

Dannecker, Petra

2005 "Transnational Migration and the Transformation of Gender Relations: The Case of Bangladeshi Labour Migrants," Current Sociology, 53(4):655-674.

De Korne, Haley, Michael Byram and Michael Fleming

2007 "Familiarising the Stranger: Immigrant Perceptions of Cross-cultural Interaction and Bicultural Identity," Journal of Multilingual and Multicultural Development, 28(4):290307. 
Devraj, Ranjit

2001 "ASIA: Migrant Workers Go into High-risk Sexual Relationships." Inter Press Service IPS-ONLINE, World Desk. Available at http://www.aegis.com/news/ips/2001/ IP011205.html, accessed on 6 June 2008.

Elson, Diane and Ruth Pearson

1981 “'Nimble Fingers Make Cheap Workers': An Analysis of Women's Employment in Third World Export Manufacturing," Feminist Review, 7(1):87-107.

Export Processing Zone Administration

2007 "Statistics on Enterprises by Category." Ministry of Economic Affairs. Available at http://en.epza.gov.tw/, accessed on 23 June 2008.

2002 "Transforming Taiwan for the Global Economy." Ministry of Economic Affairs. Available at http://en.epza.gov.tw/, accessed on 23 June 2008.

Falk, William W. and Carol Sonenfeld

1974 "Self Theory and the Twenty Statements Test: Some Thoughts on Its Application to Women." Paper presented at meeting of the Texas Academy of Science, Denton, Texas, March. Available at http://eric.ed.gov/ERICWebPortal/contentdelivery/servlet/ ERICServlet?accno=ED110397, accessed on 6 June 2008.

Fordham, Signithia and John Ogbu

1986 "Black Student's School Success: Coping with the Burden of 'Acting White'," Urban Review, 18(1):176-206.

Gecas, Viktor and Peter Burke

1995 "Self and Identity." In Sociological Perspectives on Social Psychology. Edited by Karen Cook, Gary Fine and James House. Boston, MA.: Allyn and Bacon.

Glaser, Barney and Anselm Strauss

1967 Discovery of Grounded Theory. Strategies for Qualitative Research. Chicago, Illinois: Aldine Publishing Company.

Heering, Liesbeth, Rob van der Erf, and Leo van Wissen

2004 "The Role of Family Networks and Migration Culture in the Continuation of Moroccan Emigration: A Gender Perspective," Journal of Ethnic and Migration Studies, 30(2): 323-337.

Hong, Ying-yi et al.

2001 "Cultural Identity and Dynamic Construction of The Self: Collective Duties And Individual Rights," Social Cognition, 19(3):251-269.

Kanagawa, Chie, Susan E. Cross and Hazel Rose Markus

2001 "'Who Am I?' The Cultural Psychology of the Conceptual Self," Personality and Social Psychology Bulletin, 27(1):90-103.

Kuhn, Manford H. and Thomas S. McPartland

1954 "An Empirical Investigation of Self-Attitudes," American Sociological Review, 19(1):6876. 
Kühnen, Ulrich, Bettina Hannover and Benjamin Schubert

2001 "The Semantic-Procedural Interface Model of the Self: The Role of Self-Knowledge for Context-Dependent versus Context-Independent Modes of Thinking," Journal of Personality and Social Psychology, 80(1):397-409.

Kung, Lorna

2003 "Overview of the Foreign workers in Taiwan." Oral presentation to the Second Diocesan Coordinators Meeting, Stella Maris InternationalService Center, Kaohsiung, Taiwan, 2-4 July.

Lan, Pei-Chia

2006 GlobalCinderellas:Migrant Domestics and Newly Rich Employersin Taiwan. Durham, NC: Duke University Press.

2003 "Exoticizing Labor and Nationalizing State: Foreign Labor Policy and Migrant Communities in Taiwan." Paper presented at the World Hakka Culture Conference, Kaohsiung, Taiwan, 12-16 November.

Law, Kam-yee and Kim-ming Lee

2006 "Citizenship, Economy and Social Exclusion of Mainland Chinese Immigrants in Hong Kong," Journal of Contemporary Asia, 36(2):217-242.

Lay, Clarry and Maykel Verkuyten

1999 "Ethnic Identity and Its Relation to Personal Self-Esteem: A Comparison of CanadianBorn and Foreign-Born Chinese Adolescents," Journal of Social Psychology, 139(3):288299.

LeCompte, Margaret and Jean Schensul

1999 Designing and Conducting Ethnographic Research. Volume 1. The Ethnographer's Toolkit. Oxford: AltaMira Press.

Lee, Joseph S. and Su-Wan Wang

1996 "Recruiting and Managing of Foreign Workers in Taiwan," Asian and Pacific Migration Journal, 5(2-3):281-301.

Lin, Chin-ju

1999 "Filipina Domestic Workers in Taiwan: Structural Constraints and Personal Resistance." Taiwan Grassroots Women Workers' Centre. Available at http://www. womenweb.org.tw/English/Uploads/\%7BEC29C8CB-05C2-4319-8C19-039258C8BD 04\%7D_chinjulin\%20total.pdf, accessed on 6 June 2008.

Lindio-McGovern, Ligaya

2004 "Alienation and Labor Export in the Context of Globalization: Filipino Migrant Domestic Workers in Taiwan and Hong Kong," Critical Asian Studies, 36(2):217-238.

Loveband, Anne

2004 "Positioning the Product: Indonesian Migrant Women Workers in Contemporary Taiwan," Journal of Contemporary Asia, 34(3):336-348. 
Lu, Chien-Yi

2000 "Politics of Foreign Labor Policy in Taiwan," Journal of Asian and African Studies, 35(1):113-131.

Martin, Philip

1993 "Migration and Trade: The Case of the Philippines," International Migration Review, 27(3):639-645.

Martin, Philip, Manolo Abella and Elizabeth Midgley

2004 "Best Practices to Manage Migration: The Philippines," International Migration Review, 38(4):1544-1559.

Massey, Douglas et al.

1993 "Theories of International Migration: A Review and Appraisal," Population and Development Review, 19(3):431-466.

McPhail, Clark and Charles W. Tucker

1972 "The Classification and Ordering of Responses to the Question 'Who Am I?'," The Sociological Quarterly, 13(3):329-334.

Mead, George Herbert

1962 Mind, Self, and Society. Chicago, IL: University of Chicago Press.

Mission for Migrant Workers

2008 "Overcharging by Recruitment Agencies and Burdensome Philippine Government Fees Eat Up Wages and Remittances of Filipino Migrant Workers." Available at http:/ /www.migrants.net/_resources/files/SURVEY_FINAL_REPORT.pdf, accessed on 6 June 2008

Oishi, Nana

2005 Women in Motion: Globalization, State Policies, and Labor Migration in Asia.Stanford, CA: Stanford University Press.

Parre as, Rhacel Salazar

2005 Children of Global Migration: Transnational Families and Gendered Woes. Stanford, CA: Stanford University Press.

2001 Servants of Globalization: Women, Migration, and Domestic Work. Stanford, CA: Stanford University Press.

Piper, Nicola

2006 "Gendering the Politics of Migration," International Migration Review, 40(1):133-164.

2004 "Rights of Foreign Workers and the Politics of Migration in South-East and East Asia," International Migration, 42(5):71-97.

Poortinga, Ype H. and Dianne A. Van Hemert

2001 "Personality and Culture: Demarcating Between the Common and the Unique," Journal of Personality, 69(6):1033-1060. 
Portes, Alejandro and Rubén Rumbaut

1996 Immigrant America: A Portrait. $2^{\text {nd }}$ ed. Berkeley, CA: University of California Press.

Ratha, Dilip and William Shaw

2007 "South-South Migration and Remittances." World Bank Working Paper No. 102. Development Prospects Group. Washington, DC: The International Bank for Reconstruction and Development. Available at http://go.worldbank.org/24HSQRXN31, accessed on 6 June 2008.

Sanders, Jimy M.

2002 "Ethnic Boundaries and Identity in Plural Societies," Annual Review of Sociology 28(1):327-357.

Sapru, Saloni

2006 "Parenting and Adolescent Identity: A Study of Indian Families in New Delhi and Geneva," Journal of Adolescent Research, 21(5):484-513.

Semyonov, Moshe and Anastasia Gorodzeisky

2005 "Labor Migration, Remittances and Household Income: A Comparison between Filipino and Filipina Overseas Workers," International Migration Review, 39(1):45-68.

2004 "Occupational Destinations and Economic Mobility of Filipino Overseas Workers," International Migration Review, 38(1)5-25.

Sills, Stephen

2007 "Philippine Labor Migration to Taiwan: Social, Political, Demographic, and Economic Dimensions," Migration Letters, 4(1):1-14.

Skeldon, Ronald

1992 "International Migration Within and From the East and Southeast Asian Region: A Review Essay," Asian and Pacific Migration Journal, 1(1):19-63.

Smith, Peter and Michael Bond

1998 Social Psychology Across Cultures. Boston, MA: Allyn and Bacon.

Stalker, Peter

2000 Workers Without Frontiers: The Impact of Globalization on International Migration. Geneva: International Labour Office.

1994 The Work of Strangers: A Survey of International Labour Migration. Geneva: International Labour Office.

Stein, Nicholas

2003 "No Way Out Competition to Make Products for Western Companies Has Revived an Old Form of Abuse: Debt Bondage," Fortune, January 20, 2003. Available at http:// money.cnn.com/magazines/fortune/fortune_archive/2003/01/20/335632/index. htm, accessed on 6 June 2008. 
Stets, Jan and Peter Burke

2000 "Identity Theory and Social Identity Theory," Social Psychology Quarterly, 63(3):224237.

Tajfel, Henri and John Turner

1986 "The Social Identity Theory of Intergroup Behavior." In Psychology of Intergroup Relations. Edited by Stephen Worchel and William Austin. Chicago, IL: Nelson Hall.

Taipei Times

2002 "Message from the President," Taipei Times, 12 June 2002, p. 18. Available at http:// www.taipeitimes.com/News/supplement/archives/2002/06/12/140090, accessed on 6 June 2008.

Tan, Edita

2001 "'Labor Market Adjustments to Large Scale Emigration: The Philippine Case'," Asian and Pacific Migration Journal, 10(3-4):379:400.

Tierney, Robert

2007 "The Guest Labor System in Taiwan," Critical Asian Studies, 39(2):205-228.

Tseng, Winston

2007 "Social Conditions of Foreign Laborers in a Meatpacking Factory in Rural Southern Taiwan," Research in Economic Anthropology, 25(1):51-73.

Tyner, J. A.

1999 "The Global Context of Gendered Labor Migration from the Philippines to the United States," American Behavioral Scientist, 42(4):671-689.

United Nations

2006 "International Migration 2006." Department of Economic and Social Affairs - Population Division. Available at http://www.un.org/esa/population/publications/2006 Migration_Chart/Migration2006.pdf, accessed 6 June 2008.

Verkuyten, Maykel

1991 "Self-Definition and Ingroup Formation Among Ethnic Minorities in the Netherlands," Social Psychology Quarterly, 54(3):280-286.

Villalba, Maria Angela "Mayan"

2002 "Philippines: Good Practices For The Protection Of Filipino Women Migrant Workers In Vulnerable Jobs." GENPROM Working Paper No. 8. Series on Women and Migration Geneva, Switzerland: Gender Promotion Programme International Labour Office. Available at http://www.popline.org/docs/325142, accessed on 6 June 2008.

Wang, Li-jung

2005 "The Formation of 'Transnational Communities': A New Challenge to 'Multicultural Taiwan'," International Journal of Cultural Policy, 11(2):171-185.

Watkins, David and Andres Gerong

1997 "Culture and Spontaneous Self-Concept among Filipino College Students," Journal of Social Psychology, 137(4):480-488. 
Yeoh, Brenda

2006 "Bifurcated Labour: The Unequal Incorporation of Transmigrants in Singapore," Journal of Economic and Social Geography, 97(1):95-118.

Yeoh, Brenda and Louisa Khoo

1998 "Home, Work and Community:Skilled International Migration and Expatriate Women in Singapore," International Migration, 36(2):159-86.

Young, Ken

2004 "Globalisation and the Changing Management of Migrating Service Workers in the Asia Pacific," Journal of Contemporary Asia, 34(3):287-303.

Zlotnik, Hania

2003 “The Global Dimensions of Female Migration," Migration Information Source Migration Policy Institute. Available at http://www.migrationinformation.org/Feature/ display.cfm?ID=109, accessed on 6 June 2008.

Zontini, E.

2004 "Immigrant Women in Barcelona: Coping with the Consequences of Transnational Lives," Journal of Ethnic and Migration Studies, 30(6):1113-1144. 